\title{
PENGEMBANGAN TRAINER MIKROKONTROLER BERBASIS ARDUINO NANO PADA MATA PELAJARAN TEKNIK PEMROGRAMAN, MIKROPROSESOR DAN MIKROKONTROLER KELAS XI
}

\author{
Kardo Simanjuntak ${ }^{1}$, Panahatan2 \\ ${ }^{1,2}$ Pendidikan Teknik Elektro, Fakultas Teknik Universitas Negeri Medan \\ kㅏ.jo.juntak8@gmail.com
}

\begin{abstract}
This study aims to determine how the process of developing a Microcontroller Trainer as a learning medium and producing a Microcontroller trainer that has been developed is feasible as a learning medium. This research uses research and development methods. The steps for developing the Arduino Nano trainer include: (1) Potential and Problems; (2) Data Collection; (3) Product Design; (4) Design Validation; (5) Design Revision; (6) Product Trial; (7) Product Revision; (8) Trial of Use; (9) Product Revision; (10) Determination of Trainer Eligibility. The object of this research is the Arduino Nano Microcontroller Trainer. The data collection method in this study used a trainer requirements test validation questionnaire and a trainer validation test. The trainer requirement test was conducted on the Expert Practitioners and the trainer validation test was conducted on the Media Expert. Technical analysis of the data used in this study is descriptive qualitative, quantitative and descriptive statistics. The result of this research is the Arduino Nano Microcontroller Trainer which consists of IR sensor input devices, light sensors and output devices such as LEDs, LCD Matrix, Dot Matrix, Seven Segment Displays, Relays, DC Motors and Buzzers. The results of the trainer requirements test by Expert Practitioners are $92.5 \%$ (very feasible) and the results of the trainer validation test by Media Experts are $91.25 \%$ (very feasible). Based on the total scores of the trainer requirements test results and the results of the media validation test, it was concluded that the Arduino Nano-Based Microcontroller Trainer was very suitable to be used as a learning medium for class XI TAV at SMK N.1 Lubuk Pakam.
\end{abstract}

Keywords: Learning Media Trainer, Arduino Nano,

\begin{abstract}
Abstrak
Penelitian ini bertujuan untuk mengetahui bagaimana proses pengembangan Trainer Mikrokontroler sebagai media pembelajaran dan Menghasilkan trainer Mikrokontroler yang telah dikembangkan layak sebagai media pembelajaran. Penelitian ini menggunakan metode penelitian pengembangan (research and development). Langkah-langkah pengembangan trainer Arduino Nano ini meliputi : (1) Potensi Dan Masalah; (2) Pengumpulan Data; (3) Desain Produk; (4) Validasi Desain; (5) Revisi Desain; (6) Uji Coba Produk; (7) Revisi Produk; (8) Uji Coba Pemakaian; (9) Revisi Produk; (10) Penetapan Kelayakan Trainer. Objek pada penelitian ini adalah Trainer Mikrokontroler Arduino Nano. Metode pengumpulan data pada penelitian ini menggunakan angket validasi uji persyaratan trainer dan uji validasi Trainer. Uji persyaratan trainer dilakukan terhadap Ahli Praktisi dan uji validasi trainer dilakukan terhadap Ahli Media. Teknis analisis data yang digunakan pada penelitian ini adalah deskriptif kualitatif, kuantitatif dan statistik deskriptif. Hasil penelitian in adalah Trainer Mikrokontroler Arduino Nano yang terdiri dari piranti input sensor IR, Sensor cahaya dan piranti output seperti LED, LCD Matriks, Dot Matriks, Peragah Seven Segmen, Relay, Motor DC dan Buzzer. Hasil uji persyaratan trainer oleh Ahli Praktisi sebesar 92,5\% (sangat layak) dan hasil uji validasi trainer oleh Ahli Media sebesar 91,25\% (sangat layak). Berdasarkan jumlah skor hasil uji persyaratan trainer dan hasil uji validasi media disimpulkan bahwa Trainer Mikrokontroler Berbasis Arduino Nano sangat layak digunakansebagai media pembelajaran untuk kelas XI TAV di SMK N.1 Lubuk Pakam.
\end{abstract}

Kata Kunci : Media Pembelajaran Trainer, Arduino Nano, 


\section{PENDAHULUAN}

Perkembangan teknologi yang sangat pesat di era globalisasi saat ini telah memberikan banyak manfaat dalam kemajuan diberbagai aspek sosial. Penggunaan teknologi oleh manusia dalam membantu menyelesaikan pekerjaan merupakan hal yang menjadi keharusan dalam kehidupan. Perkembangan teknologi ini juga harus diikuti dengan perkembangan pada Sumber Daya Manusia (SDM). Manusia sebagai pengguna teknologi harus mampu memanfaatkan teknologi yang ada saat ini, maupun perkembangan teknologi tersebut selanjutnya. Adaptasi manusia dengan teknologi baru yang telah berkembang wajib untuk dilakukan melalui pendidikan. Hal ini dilakukan agar generasi penerus tidak tertinggal dalam hal teknologi baru. Dengan begitu, teknologi dan pendidikan mampu berkembang bersama seiring dengan adanya generasi baru sebagai penerus generasi lama. Beberapa cara adaptasi tersebut dapat diwujudkan dalam bentuk pelatihan maupun pendidikan.

Pendidikan merupakan sebuah sarana yang efektif dalam mendukung perkembangan serta peningkatan sumber daya manusia menuju ke arah yang lebih positif. Kemajuan suatu bangsa bergantung kepada sumber daya manusia yang berkualitas, dimana hal itu sangat ditentukan dengan adanya pendidikan. Jika kualitas pendidikan tersebut rendah maka kualitas sumber daya manusia yang dihasilkannya kurang maksimal. Dalam meningkatkan kualitas pendidikan maupun pembelajaran lembaga pendidikan (sekolah) menjadi salah satu sarana yang penting dalam mewujudkannya. Salah satunya adalah SMK (Sekolah Menengah Kejuruan) yang merupakan suatu lembaga pendidikan yang berorientasi untuk menghasilkan individu-individu dengan kualitas sumber daya manusia yang memiliki tingkat kompetensi yang mampu diterima di dunia kerja/industri. Dan itu semua tidak terlepas oleh peran seorang pendidik/guru, metode pembelajaran, dan media pembelajaran yang tepat diberikan oleh guru pada siswa.

Sekolah Menengah Kejuruan (SMK) termasuk dalam undang-undang Sisdiknas No. 20 Tahun 2003 pada BAB 4, Bagian ketiga tentang pendidikan pendidikan menengah. Sekolah menengah kejuruan melaksanakan pendidikan sebagaimana diatur dalam Undang-Undang Sisdiknas Nomor 20 Tahun 2003 tentang sistem pendidikan nasional menyebutkan, Pendidikan adalah usaha sadar dan terencana untuk mewujudkan suasana belajar dan proses pembelajaran agar peserta didik secara aktif mengembangkan potensi dirinya untuk memiliki kekuatan spiritual keagamaan, pengendalian diri, kepribadian, kecerdasan, akhlak mulia, serta keterampilan yang diperlukan dirinya, masyarakat, bangsa dan negara. Pendidikan menengah tersebut juga dapat diartikan sebagai pendidikan yang mempersiapkan peserta didik untuk dapat bekerja dalam bidang tertentu. sebagai contoh Salah satu pendidikan kejuruan yaitu SMK Negeri 1 Lubuk Pakam yang terdapat di Kabupaten Deli Serdang Sumatera Utara dimana sekolah ini juga yang menjadi tempat landasan untuk diadakan penelitian. Sekolah Menengah kejuruan (SMK) ini memiliki beberapa bidang keahlian salah satunya bidang keahlian Teknik Audio vidio yang terdiri dari beberapa program keahlian dan kompetensi keahlian salah satunya adalah materi pembelajaran yang terdapat pada mata pelajaran Teknik Pemrograman, Mikroprosessor dan Mikrokotroler. Mata pelajaran teknik Teknik Pemrograman, Mikroprosesor Dan Mikrokontroler adalah salah satu mata pelajaran produktif disekolah menengah kejuruan (SMK) untuk kompetensi keahlian Teknik Audio Video. Mata pelajaran ini menjelaskan tentang pemrograman yang ada terkait pada mikroprosesor dan mikrokontroler.

Perlu diketahui bahwa mikroprosesor dan mikrokontroler merupakan sebuah alat yang dapat digunakan untuk membantu para teknisi dalam mempermudah membuat sebuah aplikasi elektronika. Mungkin pada zaman sebelum ditemukan mikroprosesor atau mikrokontroler para teknisi masih menggunakan rangkaian analog, namun seiring perkembangan zaman muncullah mikroprosesor dan mikrokontroler yang mempermudah membuat aplikasi elektronika menggunakan sistem digital dan mempermudah pengerjaan dibagian sistem industri. Hal tersebut yang menjadi salah satu mendorong untuk ditetapkan mata pelajaran sistem pemrograman, mikroprosesor dan mikrokontroler di Pendidikan kejuruan tepatnya SMK Agar setiap siswa kelulusan pendidikan Kejuruan mampu memahami pemgrograman secara baik. Mengingat hal tersebut, SMK N. 1 Lubuk Pakam juga sudah menerapkan adanya mata pelajaran teknik pemrograman, mikroprosesor dan mikrokontroler dan mata pelajaran tersebut mulai ada pada Tahun 2017. Sudah kurang lebih 3 tahun mata pelajaran teknik pemrograman, mikroprosesor dan mikrokontroler diterapkan disekolah namun alat dan bahan yang digunakan sebagai contoh sekaligus bahan praktek belajar sampai saat ini juga masih belum ada sehingga menyebabkan siswa sama sekali kurang memahami secara mendalam mengenai teknik pemrograman, mikroprosesor dan mikrokontroler. Hal ini diketahui juga melalui wawancara terhadap siswa. 
Berdasarkan wawancara yang dilakukan terhadap guru dan siswa potensi siswa kelas XI kompetensi keahlian Teknik Audio Video dalam bidang Mikroprosesor dan Mikrokontroler mayoritas siswa tergolong gaya belajar Auditori Dan guru mengajar yaitu dengan metode ceramah atau demontrasi dengan kata lain model pembelajarannya menggunakan model konvensional. Hal inilah pada akhirnya hasil belajar mereka masih terdapat yang tidak berkompeten dalam bidang mata pelajarannya dan pemahaman masih terbilang rendah. Diperoleh juga data bahwa, dalam pembelajaran Mikro-prosesor dan Mikrokontroler masih banyak siswa yang belum mencapai Kriteria Ketuntasan Minimal KKM yang ditetapkan yaitu 75 terbukti dari nilai rata-rata kelas yang hanya mencapai 65, sementara dilihat dari ketuntasan individu berdasarkan KKM, dan data ini ternilai dari perolehan melalui 25 siswa hanya 11 orang siswa (44\%) yang telah mendapat nilai baik, sedangkan 14 orang siswa (56\%) belum mencapai KKM.

Wawancara yang dilakukan terhadap beberapa siswa kelas XI kompetensi Mikroprosesor dan Mikrokontroller mengenai Masalah yang di alami oleh siswa kelas XI kebanyakan dari mereka menyebutkan bahwa mereka jarang mengadakan praktek, sehingga ketika muncul pertanyaan apakah mereka mengenal bahasa pemrograman, jenis pemrograman apa yang diketahui, apakah pernah melakukan praktek mengenai pembuatan pemrograman sederhana seperti Led Berkedip, Running Led, mengontrol cahaya led dengan PWM, mengontrol Running Led, mengontrol relay menggunakan sensor IR, bunyi "beep" pada buzzer aktif dan lain sebagainya lalu jawaban dari setiap siswa sangat tidak mengetahui dan yang menjadi alasan mereka tidak mengatahui karena tidak ada praktek..

Pertanyaan juga muncul tentang apakah anda mengenal Trainer, dan mereka juga serentak menjawab belum mengenal Trainer karena belum adanya Trainer di sekolah mereka. Hal ini Dikarenakan fasilitas sekolah yang belum memiliki trainer, masalah tersebut sangat menghambat siswa memahami materi pembelajaran didalam teori maupun praktik. Berdasarkan kondisi tersebut adanya potensi membuat Trainer mikrokontroler sebagai media belajar yang diharapkan dapat menunjang kegiatan praktikum siswa sehingga proses belajar mengajar dapat dilakukan dengan lebih optimal.

Trainer Mikrokontroler ini sangat penting dan menarik untuk diteliti, Trainer ini disertai dengan jobsheet (lembar kerja) agar dapat melatih logika pemrograman siswa untuk mendalami secara jelas mengenai pemrograman. Produk yang dihasilkan dalam penelitian ini adalah Trainer Arduino Nano sebagai media pembelajaran untuk digunakan dalam kegiatan praktikum siswa.

Berdasarkan uraian di atas, maka penulis berinisiatif mengambil judul "Pengembangan Trainer Mikrokontroler Berbasis Arduino Nano Pada MataPelajaran Teknik Pemrograman, Mikroprosesor Dan Mikrokontroler Kelas XI Kompetensi Keahlian Teknik Audio Video Di SMK Negeri 1 Lubuk Pakam.

\section{Pengembangan Trainer Mikro-kontroler Berbasis Arduino Nano Pengembangan}

Istilah pengembangan (development) hampir dapat diartikan secara dekat dengan pertumbuhan (growth). dapat diartikan adanya perubahan dari suatu keadaan menjadi keadaan yang lain. Menurut Nizar Syaefrudin (2016:7) dikutip dari Ibrahim, Penelitian pada hakekatnya Mencari jawaban atas masalah yang menuntut jawaban yangbenar, setidaknya mendekati kebenaran yang logis menurut penalaran manuasia dan didukung oleh fakta empiris. Hakikat penelitian dipandang sebagai upaya menjawab permasalahan secara sistematik dengan metode-metode tertentu melalui pengumpulan data empiris dan menarik kesimpulan atas jawaban masalah tersebut.

Menurut Prof.Dr. Nana Syaodih Sukmadinata dalam bukunya (2017:164) dijelaskan bahwa penelitian dan pengembangan (research and development) adalah suatu proses atau langkah-langkah untuk mengembangkan suatu produk baru atau menyempurnakan produk yang telah ada yang dapat dipertanggung jawabkan dan produk tersebut tidak selalu berbentuk benda ataupun perangkat keras, sepertu buku, modul, alat bantu pembelajaran dikelas maupun dilaboratorium, tetapi bisa juga perangkat lunak (software) seperti program komputer untuk pengolahan data, pembelajaran dikelas, perpustakaan atau laboratorium, dll.

Menurut Nizar Syaefrudin (2016:7) dalam skripsinya dikutip dari Ezmir, bahwa dalam bidang pendidikan, tujuan utama penelitian dan pengembangan bukan untuk merumuskan atau menguji teori, tetapi untuk mengembangkan produk-produk yang efektif untuk digunakan di sekolah-sekolah. Model penelitian pengembangan telah dikembangkan oleh beberapa ahli, salah satunya adalah Sugiyono (2016:407). Menurut Sugiyono (2016:407) model penelititan dan pengembangan (research and 
development) adalah model penelitian yang digunakan untuk menghasilkan produk tertentu dan menguji efektivitas produk tersebut.

\section{Model Pengembangan.}

Ada banyak model penelitian pengembangan, salah satu jenis model penelitian pengembangan yang sering digunakan pada bidang pendidikan adalah ADDIE Menurut Nur Cahyono (2016:9-11) model penelitian pengembangan ADDIE merupakan singkatan dari Analysis, Design Development or Production, Implementation or Delivery, and Evaluation yang dikembangkan oleh Dick dan Carry. Model penelitian pengembangan ADDIE sering digunakan untuk pengembangan bahan ajar seperti modul, LKS, buku ajar, dan pengembangan produk lainnya karena inti dari sebuah pengembangan produk sudah terwakili dalam metode ini. Berikut merupakan penjelasan dari proses-proses penelitian pengembangan dengan model ADDIE oleh Endang Mulyati Ningsih dalam skripsi Nur Cahyono (2016).

a. Analysis

Pada tahap ini, kegiatan utama adalah menganalisis perlunya pengembangan model/metode pembelajaran baru dan menganalisis kelayakan dan syarat-syarat pengembangan model/metode pembelajaran baru. Berikut tahap analysis:

$>$ Pemikiran tentang produk baru yang akan dikembangkan.

$>$ Mengidentifikasi produk yang sesuai dengan sasaran peserta didik, tujuan belajar, mengidentifikasi isi/materi pembelajaran, mengidentifikasi lingkungan belajar dan strategi

b. Design penyampaian dalam pembelajaran.

1) Merancang konsep produk baru.

2) Merancang perangkat pengembangan produk baru.

3) Rancangan ditulis untuk masing-masing unit pembelajaran.

4) Petunjuk penerapan desain atau pembuatan produk ditulis secara rinci.

c. Development

1) Mengembangkan perangkat produk yang diperlukan dalam pengembangan. Berbasis pada hasil rancangan produk yang sesuai dengan struktur model.

2) Membuat instrumen untuk mengukur kinerja produk.

d. Implementation

1) Memulai menggunakan produk baru dalam pembelajaran yang nyata.

2) Melihat kembali tujuan-tujuan pengembangan produk, interaksi antar peserta didik serta menanyakan umpan balik awal proses evaluasi.

e. Evaluation

1) Melihat kembali dampak pembelajaran dengan cara yang kritis.

2) Mengukur ketercapaian tujuan pengembangan produk.

3) Mencari informasi apa saja yang dapat membuat peserta didik mencapai hasil dengan baik.

\section{Trainer}

Menurut Tika Danti Saraswati (2018:8) dikutip dari Umi Rochayati dan Suprapto dalam skripsi Tika menyatakan trainer adalah suatu set peralatan di laboratorium yang digunakan sebagai sarana praktikum yang dapat meningkatkan keterampilan peserta didik. Trainer digunakan untuk menunjang pembelajaran peserta didik dalam menerapkan pengetahuan/konsep-konsep yang diperolehnya pada benda nyata sehingga dapat meningkatkan keterampilan siswa dalam praktikum.

Inggit Pangestu Rahmadiyah (2015:147), trainer adalah suatu set peralatan di laboratorium yang dapat dilihat, memiliki bentuk tiga dimensi dan dapat digunakan sebagai media pendidikan. Trainer digunakan untuk menunjang pembelajaran peserta didik dalam menerapkan pengetahuan/konsepkonsep yang di perolehnya pada benda nyata sehingga dapat meningkatkan keterampilan siswa dalam praktik.

\section{Mikrokontroler}

Menurut Riza Lukman dalam Skripsinya (2017:31) Mikrokontroler secara bahasa berasal dari kata " micro " yang berarti kecil dan kontrol yang berarti kendali, maka mikrokontrol dapat kita artikan sebagai pengendali kecil. Mikrokontroler merupakan sebuah komputer fungsional dalam sebuah chip. Mengapa mikrokontroler dapat disebut komputer fungsional karena di dalam mikrokontroler sudah terdiri atas prosesor, memori, maupun perlengkapan input output. Mikrokontroler memadukan memori 
untuk menyimpan program atau data perangkat I/O untuk berkomunikasi dengan alat luar. Pemanfaatan mikrokontroler saat ini sangat populer di bidang kendali dan instrumentasi elektronik. Mikrokontroler dalam aplikasinya digunakan sebagai pengendali secara otomatis, seperti sistem kontrol mesin, remote kontrol, mesin kantor, peralatan rumah tangga, alat berat, dan mainan. Sisem pengendalian mikrokontroler merupakan pengendalian terprogram yaitu dengan sistem program, jadi mikrokontroler akan bekerja berdasarkan program yang diberikan. Ada beberapa jenis mikrokontroler diantaranya jenis MCS, PIC dan AVR. Dalam trainer ini digunakan mikrokontroler AVR Atmega16, mikrokontroler AVR (AlvanVegard's) Mikrokontroler merupakan mikrokontroler RISC (Reduce Instruction Set Computing) 8 bit. Karena RISC inilah sebagian besar kode.

\section{Arduino Nano}

Arduino Nano dikutip dari Respository USU, merupakan salah satu papan pengembangan mikrokontroler yang berukuran kecil, lengkap dan mendukung penggunaan breadboard. Arduino Nano diciptakan dengan basis mikrokontroler ATmega328 (untuk Arduino Nano versi 3.x) atau ATmega 168 (untuk Arduino versi 2.x). Arduino Nano kurang lebih memiliki fungsi yang sama dengan Arduino Duemilanove, tetapi dalam paket yang berbeda. Arduino Nano tidak menyertakan colokan DC berjenis Barrel Jack, dan dihubungkan ke komputer menggunakan port USB Mini-B. Arduino Nano dirancang dan diproduksi oleh perusahaan Gravitech.

\section{METODE}

Metode penelitian yang digunakan dalam penelitian ini adalah metode penelitian pengembangan atau yang dikenal dengan Research And Development (R\&D). Menurut Sugiyono (2016: 407) Research And Development adalah metode penelitian yang digunakan untuk menghasilkan produk tertentu, dan menguji keefektifan produk tersebut. Penelitian ini dilaksanakan di SMK Negeri 1 Lubuk Pakam, Penelitian akan dilaksanakan pada semester Genap bulan Januari 2020 sampai dengan selesai Subjek penelitian ini adalah ahli media dan praktisi., adapun objek penelitiannya adalah Trainer Mikrokontroler berbasis Arduino Nano yang terdapat pada mata pelajaran Teknik Pemrograman, Mikroprosesor dan Mikrokontroler.

Prosedur penelitian pengembangan Trainer merujuk pada langkah-langkah penelitian pengembangan (Research and Development) oleh Sugiyono (2016:409), Yakni,

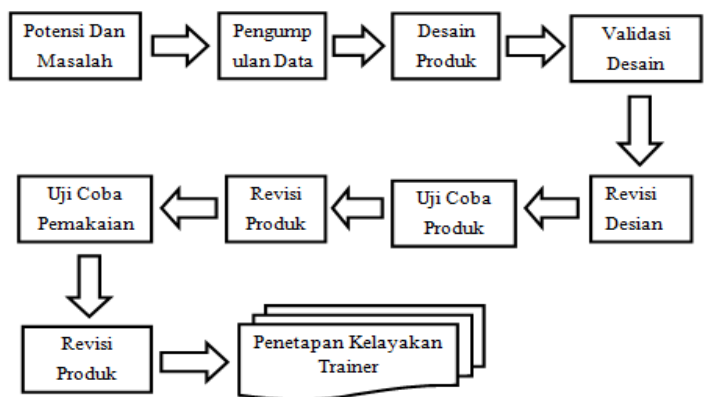

Gambar 1. Langkah-langkah Penelitian Pengembangan berikut:

Berdasarkan alur penelitian diatas maka langkah-langkah yang dilakukan adalah sebagai

1. Potensi Dan Masalah

Potensi adalah sesuatu yang bila didayagunakan akan memilih nilai tambah. sedangakan masalah adalah penyimpangan antara yang diharapkan dengan yang terjadi. Masalah ini dapat di temukan suatu model, pola, atau sistem penanganan terpadu yang efektif yang dapat digunakan untuk mengatasi masalah tersebut. Potensi dan masalah yang dikemukakan dalam penelitian harus ditunjukkan dengan data empirik.

2. Mengumpulkan Informasi

Setelah potensi dan masalah dapat ditujukan secara faktual dan uptodate, makaselanjutnya perlu di kumpulkan berbagai informasi yang dapat digunakan sebagai bahan untuk perencanaan produk tertentu yang di harapakan dapat mengatasi masalah tersebut. 
3. Desian Produk

Desain produk yang dibuat harus lengkap dengan spesifikasinya. Desain produk harus di wujudkan dalam gambar dan bagan, sehingga dapat digunakan sebagai pegangan untuk menilai dan membuatnya.

4. Validasi Desain

Validasi desain merupakan proses kegiatan untuk menilai rancanga produk. Validasi produk dapat dilakukan dengan cara mengadirkan beberapa pakar atau tenaga ahi yang sudah berpengalaman untuk menilai produk baru yang dirancang tersebut. Setiap ahli diminta untuk menilai desain produk, sehingga selanjutnya dapat diketahui kelemahan dan kekuatannya. Validasi desain dpat dilakukan dalam forum diskusi.

Pebaikan Desain

Setelah desain produk divalidasi melalui diskusi dengan pakar dan para ahlinya, maka akan dapat diketahui kelemahannya. Kelemahan tersebut selanjutnya dicoba untuk dikurangi dengan cara memperbaiki desain.

5. Uji Coba Produk

Uji coba produk dilakukan dengan terlebih dahulu membuat wujud nyata produk kemudian menguji cobanya kepada responden skala kecil dengan pemilihan responden secara acak (random).

6. Revisi Produk

Setelah di uji coba skala kecil selesai, akan diketahui kelemahan produk pada tahap awal pengujian. Selanjutnyan kelemahan tersebut akan diperbaiki untuk meminimalkan kelemahan produk pada tahap selanjutnya.

7. Uji Coba Pemakaian

Uji coba pemakaian ini dilakukan pada skala yang lebih luas, maka jumlah responden lebih banyak dibandingkan dengan tahap uji coba skala kecil.

8. Revisi Produk

Revisi produk dilakukan apabila dalam uji coba pemakaian terdapat kekurangan atau kelemahan, sehingga kelemahan tersebut dapat digunakan menjadi bahan pertimbangan untuk memperbaiki produk.

9. Pembuatan Produksi Massal

Pembuatan produk massal ini di lakukan apabila produk telah di uji coba dinyatakan efektif dan layak untuk di produksi missal.

Teknik pengumpulan data yang dilakukan dalam penelitian ini adalah angket yang berisi pernyataan-pernyataan validasi. Angket menurut Sugiyono (20016:199) merupakan teknik pengumpulan data dengan cara memberikan pertanyaan atau pernyataan secara tertulis kepada responden untuk melihat produk yang telah dikembangkan. Angket berupa lembaran yang berisi kolom pernyataan, penilaian dan komentar. Nilai yang didapat dari responden akan digunakan sebagai analisis dalam pengujian kelayakan trainer dan komentar akan digunakan sebagai bahan pertimbangan dalam merevisi trainer. Angket validasi dalam penelitian ini juga digunakan sebagai instrumen penelitian karena pengujian dalam penelitian hanya sampai pada tahap validasi. Menurut Sugiyono (2016:148) instrumen penelitian merupakan alat ukur yang akan digunakan untuk mengukur fenomena alam maupun sosial yang diamati. Karena pada prinsipnya meneliti adalah kegiatan pengukuran, maka harus ada alat ukur yang baik. Instrumen yang digunakan dalam penelitian ini diadaptasi dari syarat trainer yang dikemukakan oleh Mourdel dalam Panahatan (2009:18) dan penelitian yang dilakukan oleh Riska Indarto (2015:47-52). Jenis instrumen pada penelitian ini terdiri dari angket uji persyaratan Trainer yang diadaptasi dari Mourdel, yaitu angket pendapat ahli oleh ahli media, praktisi dan pengguna yaitu guru maupun siswa.

Menurut Teknik analisa data yang dilakukan pada tahap pertama adlah menggunakan deskriptif kualitatif, yakni memaparkan produk media hasil rancangan media pembelajaran setelah di implementasikan dalam bentuk produk jadi. Tahap kedua menggunakan deskriptif kuantitatif, yakni mengubah data kualitatif menjadi kuantitatif, selanjutnya melakukan analisa kelayakan Trainer 
menggunakan statistik deskriptif dengan cara menghitung skor rata-rata hasil penilain tiap komponen pengembangan Trainer.

Perhitungan statistik deskriptif dilakukan dengan cara mencari rerata skor total menggunakan rumus

$$
\begin{aligned}
& \qquad \bar{X}=\frac{\sum X}{n} \\
& \bar{X} \quad=\text { Skor rata-rata jawaban responden } \\
& \begin{array}{l}
\sum X=\text { Jumlah skor jawaban } \\
\boldsymbol{n} \quad=\text { Jumlah responden }
\end{array}
\end{aligned}
$$

Selanjutnya data yang didapatkan diubah ke dalam bentuk persen melihat persentase kelayakan Trainer yang dikembangkan. Rumus perhitungan pesentase skor ditulis dengan rumus berikut:

$$
\text { persentase kelayakan }(\%)=\frac{\text { Skor yang diobservasi }}{\text { Skor yang diharapkan }} \times 100 \%
$$

Selanjutnya, kategori kelayakan digolongkan menggunakan skala sebagai berikut:

Tabel 1. Interval Kategori Kelayakan

\begin{tabular}{|c|c|c|}
\hline No & $\begin{array}{c}\text { Skor dalam persen } \\
(\boldsymbol{\%})\end{array}$ & $\begin{array}{c}\text { Kategori } \\
\text { kelayakan }\end{array}$ \\
\hline 1 & $0 \%-25 \%$ & Tidak Layak \\
\hline 2 & $>25 \%-50 \%$ & Kurang Layak \\
\hline 3 & $>50 \%-75 \%$ & Layak \\
\hline 4 & $>75 \%-100 \%$ & Sangat Layak \\
\hline
\end{tabular}

Setelah dilakukan penelitian nantinya, maka didapat data dan data tersebut dihitung melalui Perhitungan statistik deskriptif, kemudian Selanjutnya data yang didapatkan diubah ke dalam bentuk persen melihat persentase kelayakan dan persentase kelayakan tersebut akan diukur sesuai angka yang terdapat pada tabel.

\section{HASIL DAN PEMBAHASAN \\ Hasil Penelitian}

Penelitian dan pengembangan ini menghasilkan sebuah media pembelajaran berupa Trainer Mikrokontroler Berbasis Arduino Nano. Tahap awal dalam pengembangan Trainer Mikrokontroler Arduino Nano adalah studi lapangan yaitu observasi dan wawancara terhadap guru di SMK N.1 Lubuk Pakam kompetensi keahlian teknik audio video. Observasi dilakukan dengan tujuan untuk mengidentifikasi kebutuhan dalam pembelajaran. Setelah diidentifikasi kemudian menganalisis apa yang menjadi kebutuhan guru maupun siswa dalam pembelajaran. Selanjutnya juga dilakukan analisis terhadap kurikulum untuk melihat kompetensi dasar materi pelajaran Teknik Pemrograman, Mikroprosesor dan mikrokontroler, hal ini bertujuan untuk menyesuaikan isi dari pada pengembangan media pembelajaran (trainer) yang dirancang.

Penyesuaian pengembangan trainer mikrokontroler dengan kompetensi dasar mata pelajaran teknik pemrograman, mikroprosesor dan mikrokontroler didapat melalui kompetensi dasar yang digunakan guru sebagai acuan proses pembelajaran. Setelah studi lapangan selesai dilaksanakan, selanjutnya trainer dikembangkan derdasarkan data yang diperoleh dari studi tersebut. trainer mikrokontroler yang dikembangkan terdiri dari 2 modul yaitu, modul A dan modul B. Modul A adalah modul utama dimana terdapat piranti input/output seperti, LCD Matriks, LED, sensor LDR, Seven segment, Buzzer aktive dan passive, push buttong, relay, Elco $1000 \mathrm{~m} F 16 \mathrm{~V}$, Resistor $10 \mathrm{~K}$. Sedangkan pada modul B terdapat juga beberapa piranti seperti sebuah papan Arduino Uno beserta beberapa Piranti lainnya seperti Motor DC, Sensor IR. Modul A dan Modul B tersebut dapat kita lihat pada Gambar. 

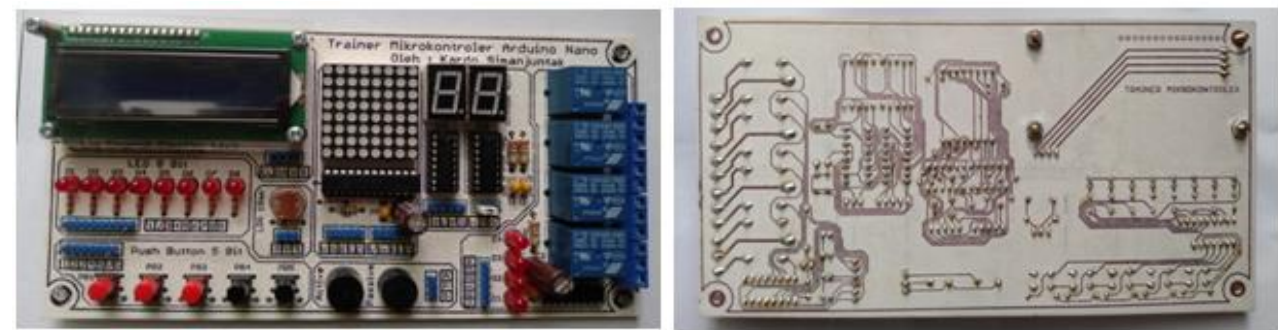

Gambar 2. Modul A trainer Beserta Layout PCB.
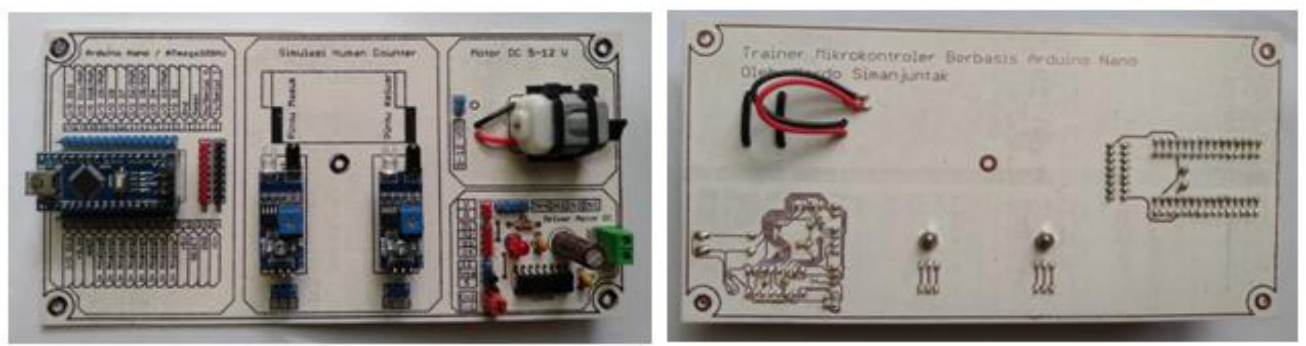

Gambar 3. Modul B trainer Beserta Layout PCB.

Setelah trainer mikrokontroler dikembangkan dan akhirnya selesai dibangun maka diadakan uji persyaratan untuk mengetahui apakah trainer yang dikembangkan telah memenuhi syarat sebagai alat pelatihan, dan uji kelayakan untuk mengetahui tingkat kelayakan trainer sebagai media, dengan menguji trainer mikrokontroler tersebut (memvalidasi) oleh orang yang berkompeten dalam bidang mikrokontroler yaitu Ahli Praktisi dan Ahli media.

\section{Hasil Uji Persyaratan Trainer Oleh Praktisi}

Validasi dilakukan dengan menggunakan angket uji persyaratan yang yang ditetapkan oleh Mourdel dalam Panahatan (2009:18). Berikut Tabel hasil validasi persyaratan trainer mikrokontroler oleh ahli praktisi.

Tabel 2. Hasil Validasi Persyaratan Trainer Mikrokontroler oleh Ahli Praktisi

\begin{tabular}{|c|c|c|c|}
\hline No Butir & \multirow{2}{*}{$\begin{array}{c}\text { Skor } \\
\end{array}$} & Maksimal & \multicolumn{2}{|c|}{ Skor Praktisi } \\
\cline { 3 - 4 } & 4 & 4 & 4 \\
\hline $\mathbf{1}$ & 4 & 3 & 4 \\
\hline $\mathbf{2}$ & 4 & 4 & 3 \\
\hline $\mathbf{3}$ & 4 & 3 & 4 \\
\hline $\mathbf{4}$ & 4 & 4 & 4 \\
\hline $\mathbf{5}$ & 4 & $\mathbf{1 8}$ & $\mathbf{1 9}$ \\
\hline \multicolumn{2}{|c|}{ Jumlah } & $\mathbf{3 , 6}$ & $\mathbf{3 , 8}$ \\
\hline \multicolumn{2}{|c|}{ Rata-Rata Skor } &
\end{tabular}

Setelah rata-rata skor dari masing-masing ahli praktisi maka selanjutnya diubah kedalam bentuk persen $(\%)$ menggunakan rumus :

$$
\text { Persentase Kelayakan (\%) }=\frac{\text { skor yang diobservasi }}{\text { skor yang diharapkan }} \times 100 \%
$$

Maka hasil persentase uji persyaratan trainer oleh masing-masing ahli praktisi yaitu:

1. Ahli Praktisi 1

$$
\text { Persentase Skor }(\%)=\frac{3,6}{4} \times 100 \%=90 \%
$$

\section{Ahli Praktisi 2}

Persentase Skor $(\%)=\frac{3,8}{4} \times 100 \%=95 \%$

Setelah hasil persentase uji persyaratan didapat, selanjutnya dibandingkan dengan persentase persyaratan pada skala pengukuran yang digunakan untuk melihat kategori pemenuhan persyaratan trainer. Skala perbandingan tersebut dapat dilihat pada tabel. 
Tabel 3. Persentase pemenuhan persyaratan.

\begin{tabular}{|c|c|c|}
\hline No Responden & Persentase & Kategori persyaratan \\
\hline Praktisi 1 & $90 \%$ & Memenuhi syarat \\
\hline Praktisi 2 & $95 \%$ & Memenuhi syarat \\
\hline Rata-Rata Persentase & $\mathbf{9 2 , 5 \%}$ & Sangat memenuhi syarat \\
\hline
\end{tabular}

Berdasarkan tabel diatas dapat diketahui hasil uji persyaratan trainer mikrokontroler oleh 2 orang ahli praktisi, ahli praktisi pertama sebesar $90 \%$ dan ahli praktisi kedua sebesar $95 \%$, kemudian persentase dari ke-2 ahli dijumlahkan lalu dicari nilai rata-rata persentasenya maka didapat nilai 92,5\%, sehingga secara keseluruhan dapat disimpulkan bahwa trainer mikrokontroler memenuhi syarat kelayakan trainer yang baik dengan kategori Sangat memenuhi syarat.

\section{Hasil Uji Validasi Trainer Oleh Ahli Media}

Setelah validasi uji persyaratan trainer selesai dilakukan, selanjutnya dilakukan uji validasi media. Validasi media dilakukan oleh 2 orang ahli media dan. Hasil validasi dapat dilihat pada tabel dibawah ini.

Tabel 4. Skor Hasil Uji Validasi Media Oleh Ahli Media.

\begin{tabular}{|l|c|c|c|}
\hline \multirow{2}{*}{$\begin{array}{c}\text { No } \\
\text { butir }\end{array}$} & \multirow{2}{*}{$\begin{array}{c}\text { Skor } \\
\text { maksimal }\end{array}$} & \multicolumn{2}{|c|}{ Skor Ahli } \\
\cline { 3 - 4 } & & Ahli Media 1 & Ahli Media 2 \\
\hline $\mathbf{1}$ & 4 & 4 & 4 \\
\hline $\mathbf{2}$ & 4 & 3 & 4 \\
\hline $\mathbf{3}$ & 4 & 4 & 4 \\
\hline $\mathbf{4}$ & 4 & 3 & 3 \\
\hline $\mathbf{5}$ & 4 & 4 & 4 \\
\hline $\mathbf{6}$ & 4 & 4 & 3 \\
\hline $\mathbf{7}$ & 4 & 3 & 4 \\
\hline $\mathbf{8}$ & 4 & 4 & 3 \\
\hline $\mathbf{9}$ & 4 & 4 & 4 \\
\hline $\mathbf{1 0}$ & 4 & 3 & 3 \\
\hline $\mathbf{1 1}$ & 4 & 3 & 3 \\
\hline $\mathbf{1 2}$ & 4 & 4 & 4 \\
\hline $\mathbf{1 3}$ & 4 & 3 & 4 \\
\hline $\mathbf{1 4}$ & 4 & 4 & 4 \\
\hline $\mathbf{1 5}$ & 4 & 4 & 4 \\
\hline $\mathbf{1 6}$ & 4 & 4 & 4 \\
\hline $\mathbf{1 7}$ & 4 & 4 & 4 \\
\hline $\mathbf{1 8}$ & 4 & 4 & 4 \\
\hline $\mathbf{1 9}$ & 4 & 3 & 3 \\
\hline $\mathbf{2 0}$ & 4 & 3 & 4 \\
\hline Jumlah & & $\mathbf{7 2}$ & $\mathbf{7 4}$ \\
\hline Rata-Rata Skor & $\mathbf{3 , 6}$ & $\mathbf{3 , 7}$ \\
\hline
\end{tabular}

Selanjutnya nilai rata-rata skor yang didapat dari masing-masing ahli media diubah dengan cara menghitung kedalam persen, berikut hasil persentase rata-rata skor ahli :

1. Ahli 1

Persentase Skor $(\%)=\frac{3,6}{4} \times 100 \%=90 \%$

2. Ahli 2

Persentase Skor $(\%)=\frac{3,7}{4} \times 100 \%=92,5 \%$

Hasil persentase skor dari masing-masing ahli media selanjutnya dibandingkan dengan skala pengukuran untuk melihat kategori kelayakan trainer. Hasil tersebut ditujukan pada tabel dibawah ini. 
Tabel 5. Persentase Kelayakan Trainer Mikrokontroler

\begin{tabular}{|l|l|l|}
\hline No responden & Persentase & Kategori Kelayakan \\
\hline Ahli Media 1 & $90 \%$ & Sangat Layak \\
\hline Ahli Media 2 & $92,5 \%$ & Sangat Layak \\
\hline Rata-Rata Persentase & $\mathbf{9 1 , 2 5 \%}$ & Sangat Layak \\
\hline
\end{tabular}

Berdasarkan tabel diatas dapat diketahui hasil uji validasi trainer mikrokontroler berdasarkan persentase kelayakan trainer oleh ahli media yaitu, ahli pertama sebesar $90 \%$, dan ahli kedua sebesar 92,5\%. Maka rata-rata persentase skor dari ke-2 ahli media tersebut yaitu sebesar 91,25\%, sehingga secara keseluruhan dapat disimpulkan bahwa trainer mikrokontroler layak digunakan sebagai media pembelajaran dengan kategori sangat layak.

\section{Pembahasan}

Tahap awal dalam pengembangan Trainer Mikrokontroler Arduino Nano adalah studi lapangan yaitu observasi dan wawancara terhadap guru di SMK N.1 Lubuk Pakam kompetensi keahlian teknik audio video. Observasi dilakukan dengan tujuan untuk mengidentifikasi kebutuhan dalam pembelajaran. Setelah diidentifikasi kemudian menganalisis apa yang menjadi kebutuhan guru maupun siswa dalam pembelajaran. Selanjutnya juga dilakukan analisis terhadap kurikulum untuk melihat kompetensi dasar materi pelajaran Teknik Pemrograman, Mikroprosesor dan mikrokontroler, hal ini bertujuan untuk menyesuaikan isi dari pada pengembangan media pembelajaran (trainer) yang dirancang.

Penyesuaian pengembangan trainer mikrokontroler dengan kompetensi dasar mata pelajaran teknik pemrograman, mikroprosesor dan mikrokontroler didapat melalui kompetensi dasar yang dapat digunakan sebagai acuan. Berdasarkan tahap penelitian diatas, maka dihasilkan sebuah trainer mikrokontroler arduino nano yang memiliki piranti input/output seperti sensor cahaya, sensor IR, LED, LCD, Dot matriks, peragah seven segment, dan piranti lainnya, dan juga disertai dengan jobsheet yang dapat membantu setiap orang yang menggunakannya untuk dilakukan percobaan.

Setelah trainer mikrokontroler dikembangkan dan akhirnysa selesai dibangun maka diadakan uji persyaratan untuk mengetahui apakah trainer yang dikembangkan telah memenuhi syarat sebagai alat pelatihan, dan uji kelayakan untuk mengetahui tingkat kelayakan trainer sebagai media, dengan menguji trainer mikrokontroler tersebut (memvalidasi) oleh orang yang berkompeten dalam bidang mikrokontroler yaitu Ahli Praktisi dan Ahli media.

Uji persyaratan dilakukan terhadap 2 orang praktisi dimana salah seorang praktisi tersebut adalah tenaga pendidik yang sangat berkompeten dibidang mikrokontroler dan salah seorangnya lagi sedang bekerja di sebuah perusahaan PT.Tobasurimi Indonusantara yang memiliki jabatan sebagai kepala bagian teknisi. Awal permulaan me-lakukan uji persyaratan yaitu dengan menunjukkan hasil bangun trainer mikrokontroler yang sudah dibangun lalu kemudian mencobanya sesuai jobsheet yang sudah disediakan.

Setelah melakukan uji coba persyaratan, kedua orang praktisi kemudian mengisi bagian angket yang dituliskan dengan tanda centang pada tabel skala penilaian lembar validasi dan kemudian memberikan kesimpulan. Hasil kesimpulan uji persyaratan oleh kedua ahli praktisi mengatakan bahwa trainer mikrokontroler tersebut layak digunakan tanpa perbaikan. hal ini berupa pemberian tanda centang pada bagian kesimpulan angket. Kemudian, Setelah tabel skala penilaian lembar validasi telah diisi oleh kedua ahli praktisi maka dilakukan perhitungan persentase untuk mengetahui skor hasil uji persyaratan. Adapun Data yang diperoleh setelah dilakukan perhitungan yaitu skor ahli praktisi 1 sebesar $90 \%$ dan ahli praktisi 2 sebesar $95 \%$. Setelah diketahui nilai persentase dari setiap ahli praktisi selanjutnya menghitung rata-rata persentase skor dimana dari ke 2 hasil persentase dijumlahkan kemudian hasil dari pada penjumlahan dibagi maka didapatlah rata-rata persentase skor sebesar 92,5 $\%$. Melihat besarnya nilai rata-rata persentase skor yaitu 92,5\% dan hal ini terdapat pada bagian ke-4 tabel interval kategori kelayakan yaitu $>75 \%-100 \%$ dapat disebut sangat layak. maka dari itu dapat disimpulkan bahwa uji persyaratan trainer memenuhi syarat kelayakan trainer dengan kategori sangat layak.

Selanjutnya Setelah trainer mikrokontroler dikembangkan dan akhirnysa selesai dibangun maka diadakan jugauji kelayakan untuk mengetahui tingkat kelayakan trainer sebagai media.Uji kelayakan dilakukan terhadap 2 orang Ahli mediatepatnya dosen pendidikan teknik elektro UNIMED. Awal permulaan melakukan uji persyaratan yaitu dengan menunjukkan hasil bangun trainer mikrokontroler 
yang sudah dibangun lalu kemudian mencobanya sesuai jobsheet yang sudah disediakan. Setelah melakukan uji coba kelayakan, kedua Ahli Media kemudian mengisi bagian angket yang dituliskan dengan tanda centang pada tabel skala penilaian lembar validasi dan kemudian memberikan kesimpulan.

Hasil kesimpulan uji kelayakan oleh kedua ahli media, dimana ahli medial mengatakan bahwa trainer mikrokontroler layak digunakan dengan perbaikan dan ahli media 2 mengatakan layak digunakan tanpa perbaikan. hal ini berupa pemberian tanda centang pada bagian kesimpulan angket. Kemudian, Setelah tabel skala penilaian lembar validasi telah diisi oleh kedua ahli media maka dilakukan perhitungan persentase untuk mengetahui skor hasil uji kelayakan media.

Adapun Data yang diperoleh setelah dilakukan perhitungan yaitu, ahli media 1 sebesar $90 \%$ dan ahli media 2 sebesar 92,5 \%, Setelah diketahui nilai persentase dari setiap ahli media selanjutnya menghitung rata-rata persentase skor dimana dari ke dua hasil persentase dijumlahkan kemudian hasil dari pada penjumlahan dibagi maka diketahuilah rata-rata persentase sebesar $91,25 \%$. Melihat besarnya nilai rata-rata persentase skor yaitu $91.25 \%$ dan hal ini terdapat pada bagian ke-4 tabel interval kategori kelayakan yaitu $>75 \%-100 \%$ dapat disebut sangat layak sehingga dapat disimpulkan bahwa trainer mikrokontroler arduino nano sangat layak digunakan sebagai media pembelajaran.

\section{SIMPULAN}

Setelah analisis data penelitian selesai dilakukan dapat diambil kesimpulan sebagai berikut :

1. Trainer mikrokontroler arduino nano dikembangkan berdasarkan data hasil analisis kebutuhan dan kurikulum (kompetensi dasar) hal ini diperoleh dari studi lapangan di SMK Negeri 1 Lubuk Pakam kompetensi keahlian Teknik Audio Video, sehingga dihasilkan Trainer Mikrokontroler Arduino Nano yang terdiri dari piranti input seperti, sensor IR, sensor cahaya, pushh button dan piranti output seperti LED, LCD Matriks, Dot Matriks, Seven Segment, Relay, Buzzer, dan Motor DC.

2. Setelah trainer selesai dibangun maka dilakukan uji validasi persyaratan trainer dan uji validasi media, hal ini dilakukan oleh orang yang berkompeten dibidang mikrokontroler yaitu Ahli Praktisi dan Ahli Media. Hasil uji persyaratan yang dilakukan oleh ahli Praktisi kedunya menyatakan bahwa trainer layak digunakan tanpa perbaikan dan data skor persentase yang diberi terhadap butir-butir aspek penilaian setelah dijumlahkan yaitu sebesar 92,5 \%dengan kategori sangat memenui syarat. Selanjutnya, hasil Uji validasi media oleh ahli media, data skor persentase yang diberi terhadap butir-butir aspek penilaian setelah dijumlahkan yaitu sebesar 91,25 \% dengan kategori sangat layak

Untuk pengembangan penelititan tahap selanjutnya perlu diadakannyanya pelatihan terhadap guru-guru untuk dapat mengoperasikan mikrokontroler serta dapat mengembangkan trainer mikrokontroler, serata perlu adanya kegiatan belajar tambahan untuk siswa/i yang bertujuan memperluas wawasan pemahaman mikrokontroler.

\section{DAFTAR PUSTAKA}

Cahyono, Nur. (2016). Pengembangan Trainer Sensor Sebagai Penunjang Mata Pelajaran Teknik Mikroprosesor Kelas X Progra Keahlian Elektronika Di Smk N 2 Pengasih. Skripsi. Universitas Negeri Yogyakarta Subdit Ristekdikti.

Danti Saraswati, Tika. (2018). Pengembangan Trainer Mikrokontroler Arduino Uno R3 Siswa Kelas XI Paket Keahlian Teknik Audio Video Di SMK Ma'arif Salam. Skripsi, Universitas Negeri Yogyakarta.

Hasan,Syamsuri.(2012). Analisis Perakitan Trainer Unit Berdasarkan Aplikasi Konsep Refigerasi Pada Matakuliah Sistem Pendingin. Diakses Dari Http://File.Upi.Edu/Browser.Php?Dir=Direktori/Fptk/Jur_Pend_TeknikMesin/1951040119810 31Syamsuri_Hasan/Artikel/.5 Mei 2018 Pukul 10.23 Wib.

Hidayat, Edwin. (2018). Trainer Sensor Dan Aktuator Sebagai Media Pembelajaran Pada Mata Pelajaran Sensor Dan Aktuator Untuk Kelas Xi Kompetensi Keahlian Teknik Elektronika Industri Di Smk Negeri 3 Wonosari. Skripsi,Universitas Negeri Yogyakarta.

Indartato, Riska (2015). Pengembangan Trainer Mikrokontroler At89s51 Sebagai Media Pembelajaran Pada Mata Pelajaran Pada Mata Pelajaran Mikrokontroler Program Keahlian, Teknik Elektronika Industri Di Smk Negeri 1nanggulan. Skripsi Universitas Yogyakarta. 
Lukman, Riza. (2017). Trainer Mikrokontroler Sebagai Media Pembelajaran Sistem Kontrol Untuk Siswa Kelas Xi Program Keahlian Teknik Otomasi Industri Di Smknegeri 2 Kendal. Skripsi, Universitasnegeri Yogyakarta.

Panahatan. (2009). Pengembangan Modul Pembelajaran Untuk Meningkatkan Hasil Belajar Elektronika Dasar Siswa Program Keahlian Audio-Video Smk Swasta Teladan Medan. Tesis Magister, Universitas Negeri Medan.

Pangestu R., Inggit. (2015). Pengembangan Media Pembelajaran Trainer Elektronika Digital Untuk Mata Pelajaran Teknik Elektronika Dasar. Jurnal Pendidikan Teknik Elektro. Volume 04 Nomor 01 Tahun 2015. Hal 145-153. Universitas Negeri Yogyakarta.

Prabhandita, Aditya 2012. "Pengembangan Dan Implementasi Media Pembelajaran Trainer Kit Sensor Ultrasonik pada Mata Diklat Praktik Sensor dan Transduser di SMK N 2 Depok Sleman". Skripsi Universitas Negeri Yogyakarta.

Prenky. (2019). Pengembangan Trainel PLC Berbasis Atmega328 Menggunakan Software Outsel Studio di Kelas XI Teknik Instalasi Tenaga Listrik Di SMK Swasta Imelda Medan. Skripsi, Universitas Negeri Medan.

Respository, Usu.Ac.Id. Tentang Landasan Teori Arduino Nano. Diakses Dari Https://Www.Google.Com/Search?Safe=Strict\&Client=Ms-Opera-

Mobile\&Sxsrf=Alekk00e0n9hgeth1mwab5k8pnh55Haha\%3a158554254\&Ei=Bab+2+Landas an+Teori+Arduino+Nano\%2c+Respository+Usu+Doc\&Oq_Lcp=Chntb2jpbgutz3dzl. Februari 2020 Pukul 19.00 Wib.

Romario. (2018). Pengembangan Trainer Mikrokontroler Berbasis Arduino Uno pada Mata Pelajaran Teknik Pemrograman, Mikroprosesor dan Mikrokontroler Kelas XI TAV SMK Negeri 1 Percutsei Tuan. Skripsi, Universitas Negeri Medan.

Subdit Kurikulum. (2017). Kompetensi Inti dan Kompetensidasar (Ki\&Kd) Smk/Mak. Diakses Dari psmk.kemendikbud.go.id/Konten/2505/Kompe-Tensi-Inti-Dan-Kompetensidasar-Ki-KdSmk/Mk. 18 Februari 2020pukul 20:37 Wib.

Subdit Ristekdikti. Undang-Undang Republik Indonesia No. 20 Tahun 2003 Tentang Sistem Pendidikan Nasional. Diakses dari Https://Kelembagaan.Ristekdikti.Go.Id/2003/Uu-No-20-Tahun-2003Tentang-Sistem-Pendidikan-Nasional. 18 Februari 2020 Pukul 20:37

Sudjana, Nana. (2009). Penilaian Hasil Proses Belajar Mengajar. Bandung : Pt Remaja Rosdakarya.

Sugiyono. (2016). Metode Penelitian Pendidikan Pendekatan Kuantitatif, Kualitatif, Dan R\&D. Bandung : Alfabeta.

Sukmadinata S., Nana (2017). Metode Penelitian Pendidikan. Bandung: PT. Remaja Rosdakarya.

Syaefrudin, Nizar. (2016). Pengembangan Media Pembelajaran Trainer Kit Sensor dan Aktuator untuk Meningkatkan Hasil Belajar Siswa Kelas XI pada Pelajaran Teknik Mikrokontroler di SMK YPT 1 Purbalingga. Skripsi Universitas Negeri Yogyakarta.

Zaini, Muhammad, (2017). Pengembangan Trainer Resistor dalam Rangkaian Arus Searah pada Mata Pelajaran Teknik Listrik Menggunakan Labview 2016 Berbasis Mikrokontroler Arduino Uno Di Kelas X Teknik Audio Video SMK Negeri 2 Yogyakarta. Skripsi Universitas Negeri Yogyakarta. 